\title{
PENGARUH LATIHAN DELORME TERHADAP PENINGKATAN KEKUATAN OTOT QUADRICEPS PADA PEMAIN SEPAK BOLA
}

\author{
Indri Susilawati ${ }^{1}$, Intan Primayanti ${ }^{2}$ \\ Pendidikan Olahraga dan Kesehatan, FPOK IKIP Mataram \\ Email: indrisalsa28@yahoo.com
}

\begin{abstract}
Abstrak: Penelitian ini berjudul "Pengaruh Latihan Delorme Terhadap Peningkatan Kekuatan Otot pada Pemain Sepak Bola. Sepak bola merupakan salah satu cabang olahraga yang dimainkan oleh dua tim yang saling memperlihatkan tehnik bermain yang baik, masing-masing tim terdiri dari sebelas orang, kedua tim akan berusaha memasukkan bola kedalam gawang lawan sebanyak mungkin sehingga tim yang memasukkan bola paling banyak akan memenangkan permainan. Untuk mencapai prestasi yang optimal diperlukan kekuatan dalam berlari dan menendang bola pada pemain sepak bola. Kekuatan berlari dan menendang bola di lakukan oleh otot quadriceps pada pemain sepak bola yang dapat ditingkatkan dengan latihan yang memerlukan adanya tahanan yang optimal. Salah satu cara untuk meningkatkan kekuatan otot adalah pemberian latihan Delorme. Delorme dikenal dengan Progressive Resistance Exercise (PRE) dengan menggunakan pendekatan latihan strengthening. Prosedur nya menentukan 10RM memberikan beban yang paling berat dan dapat digerakkan samai 10 kali repitisi. Tujuan penelitian ini adalah untuk mengetahui factor - faktor overload dan daya tahan otot yang mempengaruhi latihan delorme terhadap peningkatan kekuatan otot quadriceps pemain sepak bola. Metode penelitian eksperimen dengan desain penelitian pre test and post test with control design. Teknik pengambilan sampel menggunakan Purposive Sampling. Subyek penelitian berjumlah 22 orang pemain yang terbagi menjadi 2 kelompok (kelompok kontrol dan kelompok eksperimen). Tehnik analisis data, dalam penelitian mengunakan statistik deskriptif dan inferensial dengan pengolahan data mengunakan progam komputer SPPS for Windows versi 17 dengan taraf signifikan $5 \%(\alpha=0,05)$. Luaran wajib dalam penelitian ini adalah (1) Publikasi ilmiah pada jurnal nasional tidak terakreditasi ber ISSN. Luaran Tambahan (1) Accepted Artikel ilmiah dimuat di prosiding.
\end{abstract}

\section{Kata Kunci: Delorme, Kekuatan Otot Quadriceps.}

Abstract: This study entitled "Effect of Exercise Delorme on Increasing Quadriceps Muscle Strength in Football Players". Football is one of the sports played by two teams showing each other good playing techniques, each team consists of eleven people, both teams will try to put the ball into the opponent's goal as much as possible so that the team that puts the most balls will win the game. To achieve optimal performance required strength in running and kicking the ball in football players. The power of running and kicking the ball is done by the quadriceps muscle on the football player which can be increased by training that requires optimal resistance. One way to increase muscle strength is giving Delorme exercise. Delorme is known as the Progressive Resistance Exercise (PRE) by using a strengthening training approach. The procedure determines that 10RM gives the heaviest load and can be moved up to 10 repetitions. The purpose of this study was to determine the factors overload and muscular endurance that affect the delorme exercise to increase the strength of the quadriceps muscle in football players. Experimental research method with research design pre test and post test with control design. The sampling technique uses purposive sampling. The research subjects were 22 players who were divided into 2 groups (the control group and the experimental group). Technical analysis of the data in this study using descriptive and inferential statistics with data processing using the computer program SPSS for Windows version 17 with significant level of 5\% $(\alpha=0.05)$. Mandatory outcomes in this study are (1) scientific publications on non-accredited ISSN national journals. Additional outcomes (1) Accepted scientific articles published in proceedings.

Keywords: Delorme, strength of quadriceps muscle

\section{LATAR BELAKANG}

Daya tahan, kekuatan, kecepatan, kelincahan, dan kelenturan merupakan suatu komponen latihan fisik yang tidak dapat dipisahkan di dalam sepak bola, untuk mendapatkan kemampuan yang baik maka pelatih diharapkan dalam memberikan 1 
latihan untuk kelima komponen tersebut, dengan berpedoman pada teori-teori beban latihan fisik. Selain itu pelatih juga harus memberikan latihan fisik yang diharapkan dapat memberikan variasi-variasi latihan, hal ini ditunjukan agar pemain tidak merasa terbebani sehingga seberat apapun beban latihan yang diberikan tidak membebani pemain dalam melakukan latihan fisik. Begitu juga bagi pemain diharapkan hadir dalam setiap latihan fisik, karena kondisi fisik sangat berpengaruh untuk mencapai prestasi yang maksimal (Zainurid, 2001).

Untuk mencapai prestasi yang optimal diperlukan kekuatan dalam menendang bola yang baik pada atlet sepak bola. Kekuatan menendang bola di lakukan pada otot quadriceps pada pemain sepak bola yang dapat ditingkatkan dengan latihan yang memerlukan adanya tahanan yang optimal (Margaretha, 2004). Program latihan peningkatan kekuatan otot quadriceps yang baik dan sistematis dapat meningkatkan kemampuan fungsional dari sistem tubuh, serta meningkatkan komponen-komponen kondisi fisik, salah satunya yaitu kecepatan (speed). Menurut Sajoto (1995) speed adalah kemampuan seseorang untuk mengerjakan sekingkat-singkatnya. Kemampuan ini dibutuhkan oleh seorang atlet, terutama seorang pemain sepak bola. Yang diantaranya dapat melakukan sprint maksimal, dengan mempunyai speed yang baik akan membuat permainan menjadi efektif, serta membuat lawan menjadi kewalahan.

\section{Latihan delorme dikenal dengan Progressive Resistance Exercise (PRE) dengan menggunakan pendekatan latihan penguatan (strengthening). Prosedurnya menentukan 10 RM (Repetisi Maksimal) memberikan beban yang paling berat dan dapat digerakkan sampai 10 kali repitisi. Latihan metode delorme sebagai suatu jenis latihan strengthening akan menggunakan}

prinsip-prinsip untuk meningkatkan kekuatan otot (Lesmana, 2009).

\section{KAJIAN PUSTAKA}

\section{LATIHAN DELORME}

Latihan penguatan bisa dibedakan menjadi isometrik, isotonik, dan isokinetik. Latihan penguatan isometrik adalah bentuk latihan statik dimana otot berkontraksi dan menghasilkan force tanpa perubahan panjang otot dan sedikit/tanpa gerakan sendi. Latihan isometrik mudah dipelajari dan bisa meningkatkan kekuatan otot dengan cepat, tetapi manfaat fungsionalnya terbatas (Razmou, 2010). Latihan penguatan isotonik adalah latihan penguatan dinamik dengan beban konstan dimana otot berkontraksi memanjang (eksentrik) atau memendek (konsentrik) disepanjang luas gerak sendinya. Kontraksi eksentrik menyebabkan stres yang lebih besar tetapi menghasilkan kekuatan otot yang lebih besar pula. Latihan isotonik bemanfaat untuk meningkatkan kekuatan otot, daya tahan, dan power.

Latihan isokinetik adalah latihan dengan gerak terkendali sehingga gerakan terjadi melalui suatu rentang sendi pada kecepatan angular yang konstan selama otot memendek atau memanjang dengan beban dapat bervariasi. Latihan ini jarang digunakan karena memerlukan peralatan isokinetik untuk latihan dan hubungannya dengan aktivitas fungsional masih belum jelas. Latihan Delorme sebagai suatu jenis latihan strengthening akan menggunakan prinsip-prinsip untuk meningkatkan kekuatan otot. Oleh karena prinsip yang digunakan adalah prinsip-prinsip latihan strengthening, yaitu overload dan specificity, maka efek yang terjadi pada metode ini akan sama seperti pada adaptasi akibat latihan strengthening atau resistance exercise (Lesmana, 2009). 
Latihan ini menggunakan pendekatan seperti pada fase warm-up karena beban yang digunakan bertingkat dari beban rendah ke tinggi, yaitu dari $1 / 2$ dari $10 \mathrm{RM}, 3 / 4$ dari $10 \mathrm{RM}$, sampai full $10 \mathrm{RM}$. Warm-up atau sering disebut dengan pre-elimenary exercise merupakan aktifitas fisik yang membantu mempersiapkan performance latihan baik secara psikologis maupun fisiologis dan juga berfungsi untuk mengurangi resiko cedera pada sendi maupun otot.

\section{KEKUATAN OTOT QUADRICEPS}

Menurut Kisner (2008) Quadriceps merupakan suatu grup otot pada sendi lutut yang terletak pada sisi depan yang berfungsi untuk gerakan ekstensi lutut. Grup otot ini terdiri atas beberapa otot yaitu: rectus femoris, vastus medial, vastus intermedius, vastus lateral. Rectus femoris berasal dari spina illiaca anterior superior dan caput reflexum dari pinggir atas lekuk sendi panggul di dalam sulcus supra acetabular. Otot ini paling aktif pada sendi lutut ketika posisi sendi panggul ekstensi. Vastus medial berasal dari linea aspera labium medial. Jika otot ini bersama vastus lateral dilihat sebagai satu otot dan dianggap sebagai struktur bipenniform maka serabutnya sedikit miring pada arah yang berlawanan terhadap otot rectus femoris. Vastus intermedius berasal dari facies anterior dan lateral femur. Otot ini mudah dibedakan dengan vastus lateral, tetapi sangat sukar dipisahkan dari vastus medial. Otot ini menutupi otot sendi lutut yang berasal dari bagian distal menuju ke capsul articular sendi lutut dan berada di bagian belakang otot rectus femoris. Vastus lateral berasal dari facies lateral trochanter major, linea intertrochanter, tuberositas gluteal dan linea aspera labium lateral. Semua grup otot quadriceps femoris tersebut dipersarafi oleh nervus femoralis (Kisner, 2008).

\section{SEPAK BOLA}

Sepak bola merupakan salah satu cabang olahraga yang paling banyak diminati oleh seluruh kalangan masyarakat di seluruh dunia, karena olahraga ini merupakan olahraga yang melibatkan banyak orang dengan biaya yang tidak terlalu besar dan pelaksanaannya tidak terlalu rumit dibandingkan dengan olahraga lain. Dewasa ini permainan sepak bola berkembang dengan pesat di seluruh dunia, hampir semua negara melakukan pembinaan di usia dini termasuk di negar kita. Dalam hal ini pemerintah menitik beratkan pada sekolah-sekolah sebagai tempat untuk membina olahraga pendidikan termasuk sepak bola ini (Erfahza, 2014).

Daya tahan, kekuatan, kecepatan, kelincahan, dan kelenturan merupakan suatu komponen latihan fisik yang tidak dapat dipisahkan di dalam sepak bola, untuk mendapatkan kemampuan yang baik maka pelatih diharapkan dalam memberikan latihan fisik, yang memperhatikan beban latihan untuk kelima komponen tersebut, dengan berpedoman pada teori-teori beban latihan fisik. Selain itu pelatih juga harus memberikan latihan fisik yang diharapkan dapat memberikan variasi-variasi latihan, hal ini ditunjukan agar pemain tidak merasa terbebani sehingga seberat apapun beban latihan yang diberikan tidak membebani pemain dalam melakukan latihan fisik. Begitu juga bagi pemain diharapkan hadir dalam setiap latihan fisik, karena kondisi fisik sangat berpengaruh untuk mencapai prestasi yang maksimal (Zainurid, 2011).

\section{TUJUAN DAN MANFAAT PENELITIAN \\ Tujuan Penelitian}

Untuk mengetahui faktor - faktor overload dan daya tahan otot yang mempengaruhi latihan delorme terhadap 
peningkatan kekuatan otot quadriceps pemain sepak bola.

\section{Manfaat Penelitian}

a. Bagi para pemain PS IKIP Mataram dapat meningkatkan kekuatan otot tungkai dengan melakukan latihan penguatan otot quadriceps salah satunya dengan latihan delorme.

b. Bagi pelatih PS IKIP Mataram latihan delorme bisa menjadi salah satu referensi dalam memberikan latihan penguatan otot quadriceps.

c. Dalam memberikan suatu program latihan penguatan otot sebaiknya pelatih PS IKIP Mataram memperhatikan faktor-faktor seperti overload dan daya tahan otot.

d. Sebagai acuan atau landasan untuk menambah pengetahuan dan pengalaman dalam merancang dan melaksanakan penelitian dalam hal peningkatan kekuatan otot.

\section{METODOLOGI PENELITIAN}

\section{TAHAPAN TES}

Pre Test

Pre test dilakukan sebelum sampel mendapatkan perlakuan latihan delorme yaitu mengukur kekuatan otot quadriceps sampel menggunakan alat leg dynamometer. Adapun teknik pengumpulan data yang dilakukan adalah sebagai berikut:

a. Sampel memakai pengikat pinggang, kemudian berdiri dengan membengkokkan kedua lututnya hingga membentuk sudut 45', kemudian alat pengikat pinggang tersebut dikaitkan pada leg dynamometer.

b. Setelah itu sampel berusaha sekuatnya meluruskan kedua tungkainya.

c. Setelah sampel itu meluruskan kedua tungkainya dengan maksimum, lalu kita lihat jarum pada alat tersebut menunjukkan angka berapa. d. Angka tersebut menyatakan besarnya kekuatan otot tungkai sampel.

e. Skor terbaik dari tiga kali percobaan dicatat sebagai skor dalam satuan $\mathrm{kg}$, dengan tingkat ketelitian $0,5 \mathrm{~kg}$.

\section{Latihan Delorme}

Prosedur Pelaksanaan latihan delorme :

a. Tentukan kontrol beban sebesar 10 $\mathrm{RM}$

b. Sampel melakukan:

1. 10 kali pengulangan dengan beban $1 / 2$ dari $10 \mathrm{RM}$

2. 10 kali pengulangan dengan beban $3 / 4$ dari $10 \mathrm{RM}$

3. 10 kali pengulangan dengan beban 10 RM penuh

c. Setiap sesi dari latihan diselingi oleh istirahat singkat

\section{Post Test}

Pos test dilakukan setelah sampel mendapatkan perlakuan latihan delorme yaitu mengukur kekuatan otot quadriceps sampel menggunakan alat leg dynamometer. Adapun teknik pengumpulan data yang dilakukan sama seperti pada pre test.

\section{RANCANGAN PENELITIAN}

Jenis penelitian yang digunakan dalam penelitian ini adalah metode Quasi Eksperiment (eksperimen semu). Rancangan penelitian yang digunakan dalam penelitian ini adalah pre test and post test with control group design.

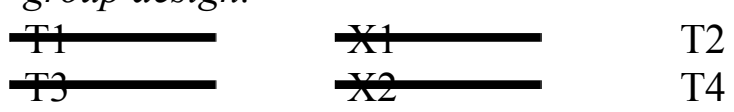

Gambar: Rancangan Penelitian

Keterangan:

T1 : Pre Test kelompok perlakuan dengan Leq Dynanometer

T2 : Post Test kelompok perlakuan dengan Leq Dynanometer

X1: Latihan Delorme pada kelompok perlakuan

X2 : Tanpa Latihan Delorme pada kelompok kontrol 
T3 : Pre Test kelompok kontrol dengan Leq Dynanometer

T4 : Post Test kelompok kontrol dengan Leq Dynanometer

TEKNIK ANALISA DATA

Dalam penelitian ini statistik probabilitas digunakan untuk mencari besarnya pengaruh latihan delorme terhadap peningkatan kekuatan otot quadriceps menggunakan rumus uji T-test. Pengolahan data yang sudah didapat dan terkumpul akan diolah menggunakan program computer SPSS for Windows versi 17.0 dengan taraf signifikan $5 \%$

\section{HASIL PENELITIAN}

\section{Tabel 01. Karakteristik Sampel}

\begin{tabular}{|c|c|c|}
\hline \multirow{2}{*}{ Karakteristik Sampel } & \multicolumn{2}{|c|}{ Rerata (Mean) } \\
\cline { 2 - 3 } & Kel 1 (n= 11) & Kel 2 (n= 11) \\
\hline Umur $($ th) & 19,636 & 20,454 \\
\hline Berat Badan $(\mathrm{kg})$ & 60,727 & 62,636 \\
\hline Tinggi Badan $(\mathrm{cm})$ & 170,454 & 169,090 \\
\hline
\end{tabular}

Keterangan :

$\mathrm{n} \quad=$ Jumlah Sampel

Kel 1 = Kelompok 1 (Latihan Delorme)

Kel 2 = Kelompok 2 (Tanpa Latihan Delorme)

Tabel 02. Hasil Uji Normalitas Data Pre-Test Pada Kedua Kelompok

\begin{tabular}{|l|c|c|c|c|c|c|}
\hline & \multicolumn{3}{|c|}{ Kolmogorov-Smirnov $^{\mathbf{2}}$} & \multicolumn{3}{c|}{ Shapiro-Wilk } \\
\cline { 2 - 7 } & Statistic & $\boldsymbol{d} \boldsymbol{f}$ & Sig. & Statistic & $\boldsymbol{d} \boldsymbol{f}$ & Sig. \\
\hline Pre test A & .136 & 11 & $.200^{*}$ & .942 & 11 & .543 \\
\hline Pre test B & .255 & 11 & .044 & .874 & 11 & .088 \\
\hline
\end{tabular}

a. Lilliefors Significance Correction

*. This is a lower bound of the true significance.

Dari data tabel uji normalitas data pre-test pada ke dua kelompok di dapatkan nilai pre-test yaitu pada kelompok A dengan nilai sig sebesar $0,543(0,543>0,05)$, sedangkan pada kelompok $\mathrm{B}$ nilai sig sebesar $0,88(0,88>0,05)$. Dengan demikian dapat disimpulkan bahwa data pada kedua kelompok dinyatakan normal.

Tabel 03. Hasil Uji Homogenitas Data Pre-Test Dan Post-Tes

\begin{tabular}{|l|c|c|c|c|}
\hline & Levene Statistic & df1 & df2 & Sig. \\
\hline Tes awal & 4.343 & 1 & 20 & .050 \\
\hline
\end{tabular}




\begin{tabular}{|l|l|l|l|l|}
\hline Tes akhir & .770 & 1 & 20 & .391 \\
\hline
\end{tabular}

Uji pengaruh perlakuan bertujuan untuk mengetahui rerata peningkatan kekuatan otot quadriceps pada kedua kelompok.

\section{Tabel 04. Rerata Peningkatan Kekuatan Otot Quadriceps Sebelum}

Dan Sesudah Perlakuan Pada Kedua Kelompok

\begin{tabular}{|c|c|c|c|}
\hline \multirow{2}{*}{ Subyek Penelitian } & \multicolumn{2}{|c|}{ Rerata (Mean) } & \multirow{2}{*}{ Selisih } \\
\cline { 2 - 3 } & $\begin{array}{c}\text { Sebelum } \\
\text { Perlakuan }\end{array}$ & $\begin{array}{c}\text { Sesudah } \\
\text { Perlakuan }\end{array}$ & \\
\hline Kelompok 1 & 110,864 & 139.273 & 28,409 \\
\hline Kelompok 2 & 110,045 & 121.000 & 10,955 \\
\hline
\end{tabular}

Dari data tabel di atas menunjukkan bahwa terjadi peningkatan rerata pada kedua kelompok, tetapi peningkatan rerata pada kelompok 1 (kelompok latihan delorme) lebih tinggi dimana selisih rerata sebelum perlakuan dengan setelah perlakuan sebesar
28,409. Sedangkan pada kelompok 2 (kelompok tanpa latihan delorme) tetap terjadi peningkatan rerata walaupun tidak diberikan latihan delorme, selisih rerata antara sebelum dan sesudah sebesar 10,955.

Tabel 05. s Paired Samples Test

\begin{tabular}{|c|c|c|c|c|c|c|c|c|c|}
\hline & \multicolumn{5}{|c|}{ Paired Differences } & \multirow[b]{3}{*}{$\mathrm{t}$} & \multirow[b]{3}{*}{$\mathrm{df}$} & \multirow{3}{*}{$\begin{array}{l}\text { Sig. (2- } \\
\text { tailed) }\end{array}$} \\
\hline & & \multirow[b]{2}{*}{ Mean } & \multirow{2}{*}{$\begin{array}{c}\text { Std. } \\
\text { Deviation }\end{array}$} & \multirow{2}{*}{$\begin{array}{l}\text { Std. Error } \\
\text { Mean }\end{array}$} & \multicolumn{2}{|c|}{$\begin{array}{l}95 \% \text { Confidence } \\
\text { Interval of the } \\
\text { Difference }\end{array}$} & & & \\
\hline & & & & & Lower & Upper & & & \\
\hline $\begin{array}{l}\text { Pair } \\
1\end{array}$ & $\begin{array}{l}\text { pretest - } \\
\text { postets }\end{array}$ & -28.4091 & 17.5539 & 5.2927 & -40.2020 & -16.6162 & -5.368 & 10 & .000 \\
\hline
\end{tabular}

Analisis kemaknaan dengan uji paired samples test menunjukkan bahwa nilai $\mathrm{t}$ adalah $-5,360$ dan nilai $\mathrm{p}$ adalah $0,000(p<0,05)$. Hal ini berarti bahwa pada kedua kelompok menghasilkan beda selisih rerata peningkatan kekuatan otot quadriceps secara bermakna dimana nilai $\mathrm{p}<0,05$ $(0,000<0,05)$.

\section{PEMBAHASAN}

PERUBAHAN

SISTEM

NEUROMUSCULAR

DALAM PENINGKATAN KEKUATAN OTOT

\section{a. Hypertropi}

Kapasitas kekuatan otot secara langsung berhubungan dengan fisiologi cross sectional area pada serabut otot. Dengan desain latihan yang spesifik dapat meningkatkan kekuatan otot, dan ukuran serabut 
otot skeletal yang disebut hypertropi. Faktor yang berperan pada hypertropi meliputi; pening-katan jumlah protein pada serabut otot, peningkatan kepadatan kapiler, perubahan bio-kimia pada serabut otot.

Walaupun masih dalam tanda tanya, diduga bahwa kekuatan otot juga dapat diting-katkan dengan resistance exercise yang menyebabkan terjadinya hyperplasia yaitu peningkatan jumlah serabut otot. Peningkatan ini dapat disebabkan oleh gerak longitudinal serabut otot. Hal ini belum bisa dipastikan karena gerak serabut otot tersebut baru dilaku-kan penelitan pada binatang.

\section{b. Recruitmen}

Faktor lain yang penting yang mempengaruhi kapasitas otot untuk meningkatkan kekuatan otot adalah peningkatan jumlah recruitmen motor unit. Banyaknya jumlah motor unit yang aktif akan menghasilkan kekuatan otot yang besar.

\section{PERUBAHAN PADA JARINGAN NONKON-TRAKTIL}

Program latihan yang didesain untuk meningkatkan kekuatan otot dapat juga meningkatkan kekuatan pada jaringan nonkontraktil seperti; tulang, tendon dan ligamen.

\section{PRINSIP UNTUK MENINGKATKAN KEKUATAN}

\section{a. Prinsip overload}

Untuk meningkatkan kekuatan otot, beban yang melebihi kapasitas metabolik otot harus digunakan selama latihan. Karena hal ini akan membuat hypertropi otot dan pening-katan recruitmen sehingga akan meningkatkan kekuatan otot.

Kapasitas otot untuk menghasilkan tegangan yang tinggi dapat dicapai dengan latihan intensitas tinggi (latihan dengan mela-wan beban berat) dan dengan repetisi yang relatif rendah.
Berdasarkan penjelasan diatas maka kekuatan otot quadriceps berarti kemampuan otot quadriceps untuk menghasilkan tegangan dan tenaga selama usaha maksimal. Untuk itu maka harus diketahui terlebih dahulu anatomi dari otot quadriceps itu sendiri.

\section{b. Daya tahan otot}

Dalam melakukan fungsinya otot tidak hanya memiliki kekuatan untuk dapat bergerak. Gerak akan menjadi fungsional bila gerakan tersebut dapat dilakukan berulang ulang. Kapasitas untuk dapat terus melakukan pengulangan aktifitas otot, seperti ketika melakukan push up dan sit up secara terus menerus dikenal dengan istilah daya tahan otot. Daya tahan otot dapat ditingkatkan melalui peningkatan kekuatan otot, juga dapat ditingkatkan dengan perubahan pada lokal metabolisme dan fungsi sirkulasi. Sesuai dengan serabut otot, maka serabut otot tipe 1 atau serabut slow twicht yang lebih banyak memiliki aliran darah dan berwarna merah memiliki daya tahan otot yang lebih baik.

Berdasarkan hasil uji statistik pada kelompok perlakuan dengan latihan delorme didapatkan nilai $\mathrm{p}<0,05$ yaitu $\mathrm{p}=0,000$ (signifikan). Hasil ini menunjukkan bahwa ada pengaruh latihan delorme terhadap peninggkatan kekuatan otot quadriceps. Semua hasil uji statistik terdapat hasil yang signifika antara kelompok perlakuan dan kontrol yang membedakan hanya selisih nilai rerata (mean). Selisih nilai rerata (mean) pada kelompok perlakuan sebesar 28,409 , sedangkan pada kelompok kontrol selisih nilai rerata (mean) sebesar 10,955. Pada kelompok kontrol terjadi peningkatan kekuatan otot quadriceps yang tidak maksimal karena peneliti memiliki keterbatasan dalam penelitian sehingga tidak 
bisa mengontrol aktivitas dan kegiatan sehari-hari seluruh sampel penelitian.

\section{KESIMPULAN}

Berdasarkan hasil uji statistik, dapat disimpulkan bahwa "Ada pengaruh latihan delorme terhadap peningkatan kekuatan otot quadriceps pada pemain PS IKIP Mataram’.

\section{DAFTAR PUSTAKA}

Erfahza. 2014. Hakikat-Sepak-Bola. Sumber. http://erfahza.blogspot.co.id. Diakses pada tanggal 10 Juni 2017.

Ganong, William F, 2010. “Buku Ajar Fisiologi Kedokteran" Edisi 17, Penerbit Buku Kedokteran EGC, Jakarta.

Kisner, C, and Colby, L. 2008. Theraupetic Exercise Foundation and Technique; Third Edition, F. A Davis Company, Philadelpia

Lesmana indra, 2012. Perbedaan Pengaruh Pemberian Latihan Metode De lorme Dengan Latihan Metode Oxford Terhadap Peningkatan
Kekuatan Otot Quadriceps. Jakarta, Esa Unggul.

Luxbacher, Josheph. 2012. Sepak Bola: Langkahlangkah Menuju Sukses. Jakarta, Rajawali Pers, 2012.

Maksum, Ali. 2009. Metodologi Penelitian Dalam Olahraga. Surabaya: UNESA.

Rahmat. 2013. Statistika Penelitian. Bandung, Pustaka Setia.

Razmjou, S. 2010. The Effects of Delorme and Oxford Techniques on Serum Cell Injury Indices and Growth Factor in Untrained Women. World Journal of Sport Sciences.3 (1): 44-52.

Sugiono.2010.Metode penelitian pendidikan pendekatan kuantitatif,kualitatif, dan R\&D. Bandung:Alfabeta

Wigianto, Didik, 2009. Permainan Sepak Bola. Jurnal Elektronik www.d12x.blog.uns.ac.id (diakses pada 13 Juni 2017).

Zainurid, 2011. Analisis Beban Latihan Fisik Pemain Sepakbola Di Klub Sepakbola "Goden Boys" BedaliLawang Kabupaten Malang. Skripsi. Program Studi Gelar Ganda, jurusan Ilmu Keolahragaan FIP Universitas Negeri Malang 